\title{
KAWIN PAKSA \\ (Problem Kewenangan Wali dan H ak Perempuan dalam Penentuan Jodoh)
}

\author{
Abu Bakar \\ (D osen STA IN Ponorogo, JL. Pramuka N 0. 156 P o.Box 116 Ponorogo)
}

\begin{abstract}
A bstract:
Religion teaching is connected with the forms of such as the freedom of choosing, deciding, and doing or not doing something in positive way. Unfortunately, the freedom often causes the problem in implementation, such as the freedom of choosing or deciding the mate that often ends in the practice of force marriage. It is a relational problem between parents and their children in deciding their children's mate because both of them keep their wish stubbornly that claim as their rights. Their parents think that they has authority in deciding their mate to their children because they think ijbar right is theirs. On the other hand, the children also think that they have the right to decide their mate by themselves. Islam protects human rights in everything including the right to their daughter in deciding their mate.
\end{abstract}

\section{Key Words:}

Kawin paksa, wali, anak perempuan, jodoh, dan hak asasi.

\section{Pendahuluan}

Globalisasi informasi dan teknologi sebagai era perubahan masyarakat dari agraris ke industrialis, telah mampu memacu percepatan penyadaran manusia tentang hak hak dasariahnya, termasuk hak-hak dasar bagi perempuan. Upaya memperjuangkan hak-hak perempuan bertujuan untuk memberi jaminan kepada perempuan tentang hak-hak dasarnya sebagai manusia seperti hakhak yang melekat pada kedudukan, posisi, dan peran sosial perempuan. Hak-hak ini secara kualitatif seharusnya seimbang dengan hak-hak yang dimiliki laki-laki. Namun dalam realitasnya, upaya tersebut sering kali mendapat tantangan bahkan dianggap 
telah merongrong tradisi dan konsep-konsep keagamaan yang rigid, resisten terhadap perubahan, dan telah mengakar kuat dalam masyarakat.

Untuk itu diperlukan adanya pendekatan (approach) dan metodologi (methodology) hukum yang lebih dinamis, fleksible dan responsif. Dalam konteks inilah, menampilkan sosok hukum Islâm, termasuk hukum perkawinan, yang humanis serta inklusif menemukan relevansi atau nilai manfaat yang signifikan. Hukum Islâm sebagai penjabaran dan aplikasi aktual syarî'ah haruslah diterjemahkan dengan mengikuti semangat zaman dan kemanusiaan sehingga inner-dinamic-nya sebagai hukum untuk manusia tidak akan kehilangan konteksnya. Di antara langkah-langkah konkrit yang dapat dilakukan adalah dengan mengintegrasikan dengan disiplin dan pendekatan ilmu-ilmu sosial dalam pengkajian hukum Islâm, khususnya yang menyangkut masalah perkawinan. Tulisan ini akan mengkaji salah satu problem perkawinan yaitu tradisi kawin paksa (ijbâr) dan hak wanita dalam menentukan jodohnya.

\section{Perkawinan dan Konstruksi Perubahan Sosial}

Ajaran Islâm merupakan konsep dasar dalam kehidupan yang memiliki nilai elastisitas dan fleksibilitas yang sesuai untuk setiap dimensi waktu-masa lalu, masa kini, dan masa yang akan datang. Untuk mengantisipasi hal tersebut, sumber dasar ajaran Islâm (alQur'ân dan Hadîts) harus mampu untuk dijadikan pedoman dalam menjawab setiap problem umat dalam hubungan vertikal maupun horisontal. Islâm tidak pernah mengajarkan sikap pemaksaan (otoritarianisme) dan diskriminatif terhadap sesama manusia. Bahkan Islâm sangat mempertimbangkan nilai-nilai persamaan, kesetaraan (al-musâwah), dan kebebasan (al-hurriyah) dalam menyelesaian problem-problem keagamaan. Setiap individu bebas melakukan perbuatan hukum dengan penuh rasa tanggung jawab, karena kebebasan individu yang satu dibatasi oleh kebebasan individu yang lain. Bahkan dalam berkeyakinan sekali pun tidak ada suatu 
paksaan. ${ }^{1}$ Oleh karena itu, perbuatan yang dilakukan atas dasar suatu tekanan, akan terbebas dari tanggung jawab. ${ }^{2}$

Ajaran agama yang termaktub baik dalam al-Qur'ân maupun Hadîts selalu mengandung unsur-unsur normatif yang bersifat transenden dan permanen serta adaptable pada setiap tempat dan waktu (shâlih likulli zamân wa makân). Walaupun demikian, ayat-ayat tersebut juga bersifat kontekstual ketika disampaikan kepada manusia. Kerangka berfikir semacam ini, sangat tepat jika digunakan untuk mempelajari pendapat seorang tokoh seperti imâm madzhab. Harus disadari bahwa para imâm madzhab ketika memformulasikan hasil ijtihâd, di samping memperhatikan nilai-nilai normatif juga berfikir dalam konteks pengalaman mereka. Bahkan tidak jarang dipengaruhi oleh "angan-angan sosial" mereka dalam merespon tantangan zaman. ${ }^{3}$

Seorang perempuan dewasa, dalam pandangan mayoritas para ulamâ', dianggap telah memiliki kemampuan untuk melakukan tindakan-tindakan hukum yang berhubungan dengan transaksitransaksi keuangan, seperti perdagangan, kepegawaian, dan sebagainya. Oleh karena itu, sangat logis jika perempuan juga dapat melakukan tindakan-tindakan yang berkaitan dengan urusan pribadinya, 4 termasuk menentukan pasangan hidupnya. Ajaran Islâm tentang perkawinan, memiliki hubungan yang kuat dengan perubahan-perubahan sosial yang terjadi. Perubahan sosial lebih

1Lihat QS. al-Baqarah (2): 256.

2Lihat riwayat Ibn Mâjah dan Bayhaqî dalam al-Sunan al-Ku brâ, Juz IV, (Berût: Dâr alFikr, t.t.), hlm. 88, dengan redaksi:

$$
\text { رفع عن أمتى الخطاء والنسيان ومااستكرهو اعليه (رواه ابن ماجه والبيهقى) }
$$

3 Hukum Islâm (figh) yang lahir dari intelektual manusia dalam fase dan penggal sejarah tertentu tidak bisa pindah begitu saja ke ruang dan waktu yang berlainan. Bagaimana pun, rumusan figh yang dikonstruksikan ratusan tahun lalu jelas terdapat celah dalam menjawab problematika umat yang begitu jama' saat ini. Jika situasi sosial, politik dan kebudayaan sudah berbeda, maka hukum sendiri harus berubah sesuai dengan ruang dan waktu. Kerancuan akan terjadi jika tetap akan memaksakan berlakunya keputusan suatu pemikiran untuk seluruh zamân dan makân, yang secara dasar pasti divergen. Lihat Ibn al-Qayyim al-Jawziyyah, I'lâm al-M uwaqqi'în 'an Rab al‘Â lamîn, juz III (Berût: Dâr al-Fikr, 1997), hlm. 14-15.

${ }^{4}$ A bd al-Rahmân al-Jazîrî, al-Figh 'alâ M adzâhib al-A rba'ah, juz IV (Beirût: Mathba'ah al-Salafiyah,t.t.), hlm. 50 . 
mudah dan cepat terjadi apabila suatu masyarakat sering mengadakan kontak dengan masyarakat lain atau telah mempunyai sistem pendidikan yang maju, sistem lapisan sosial yang terbuka, penduduk yang heterogen, serta ketidakpuasan masyarakat terhadap bidang kehidupan tertentu, dapat pula memperlancar kehidupan sosial. 5

A tas dasar itulah, kajian agama dalam perspektif sosiologis dan psikologis merupakan sebuah keniscayaan. Bukan saja karena harus bersentuhan dengan aspek "realitas" ajaran agama yang dianggap sebagai "kebenaran", namun lebih pada upaya membumikan ajaran agama tersebut sehingga tidak terkesan kaku dan rigid. Selain itu, menempatkan ajaran agama sebagai "konstruksi" normatif an sich seringkali terjebak pada pendekatan filosofis-teologis yang justru akan menjauhkan ajaran agama (konsep perkawinan) dari realitas sosial (tidak membumi).

Dalam konteks kehidupan sosial, perkawinan sering dimaknai sebagai kewajiban sosial daripada manifestasi kehendak bebas tiaptiap individu. Secara umum dapat diajukan pemikiran dalam masyarakat yang pola hubungannya bersifat tradisional, perkawinan dipersepsikan sebagai suatu keharusan sosial yang merupakan bagian dari warisan tradisi sosial. Sedangkan dalam masyarakat rasional modern, perkawinan lebih dianggap sebagai kontrak sosial dan karena itu perkawinan sering dimaknai sebagai sebuah pilihan. Dengan demikian, praktik kawin paksa yang masih berlangsung hingga saat ini adalah kemungkinan akibat kontribusi dari cara pandang terhadap perkawinan sebagai kewajiban sosial. 6

\section{Kawin Paksa (ijbâr) dalam Lintasan Literatur H ukum Islâm}

\section{Kawin Paksa dalam Perspektif AI-Q ur'ân.}

Secara umum al-Qur'ân tidak menyebutkan secara jelas tentang persoalan kawin paksa (ijbâr), akan tetapi hanya menyebutkan beberapa ayat yang menjelaskan tentang pemecahan masalah (problem

5Soerjono Soekanto, P okok-P okok Sosiol ogi H u kum, cet. 10 (Jakarta: Raja Grafindo, 2001), hlm. 99.

7Indraswati, "Fenomena Kawin Muda dan Aborsi”, dalam Syafiq Hasyim (ed.), M enakar H arga Perempuan (Jakarta: Mizan, 1999), hlm. 131-132. 
solving) dalam keluarga pada masa Nabi sebagai respon yang terjadi pada masa itu. Hal itu sesuai dengan prinsip al-Qur'ân, hanya menjelaskan prinsip-prinsip umum. Secara eksplisit al-Qur'ân menjelaskan bahwa seorang wali (ayah, kakek, dan seterusnya) tidak boleh memaksa anak perempuannya untuk menikah jika anak tersebut tidak menyetujuinya atau jika anak perempuan tersebut mau menikah dengan laki-laki pilihannya, sementara seorang wali enggan atau tidak mau menikahkannya. AI-Qur'ân surat al-Baqarah: 234 menyebutkan: "A pabila kamu menceraikan istri-istrimu, lalu habis masa iddahnya, maka janganlah kamu menghalangi mereka kawin lagi dengan cal on suaminya apalagi telah terdapat kerelaan di antara mereka dengan cara yang ma'ruf".

Tafsir terhadap ayat tersebut, sebagaimana dijelaskan al-Jazîrî adalah: (a) Khithâb ayat tersebut diperuntukkan kepada para wali (ayah, kakek, dan saudara laki-laki) untuk tidak menolak menikahkan perempuan yang ada di bawah perwaliannya. Hal ini menunjukkan bahwa keberadaan wali nikah pada masa Nabi ada dan eksis, sehingga perkawinan tanpa adanya wali tidak dibenarkan, (b) khithâb tersebut diperuntukkan kepada masyarakat umum, (c) sebagai konskuensinya, bahwa enggan menikahkan atau sebaliknya memaksa menikahkan sama-sama tidak dibenarkan, dan (d) dari sinilah secara implisit membolehkan wanita untuk menikah sendiri dan tidak seorang pun boleh menolaknya asal ada kebaikan di masa depannya. ${ }^{7}$ Dari zhahir ayat tersebut dapat difahami, bahwa seorang wali tidak boleh semena-mena terhadap anak perempuan yang berada di bawah perwaliannya, baik untuk memaksa menikah dengan pilihan wali atau sebaliknya enggan menikahkan karena tidak sesuai dengan pilihan wali.

\section{Kawin Paksa dalam Perspektif Hadîts dan Ulamâ' Fiqih.}

Pada dasarnya banyak hadîts yang baik secara langsung maupun tidak langsung membahas tentang hak ijbâr dan hak memilih jodoh. Namun penulis hanya akan merujuk beberapa hadîts yang secara khusus dipakai oleh banyak riwayat yang ada hubungannya dengan dua hal tersebut, di antaranya adalah: Barang siapa perempuan yang menikah tanpa adanya izin dari walinya, maka nikahnya batal, maka

9al-Jazâi rî, al-Fiqh ‘A lâ M adzâhib, hlm. 48-49. 
nikahnya batal, maka nikahnya batal. A pabila dia telah melakukan hubungan seksual, maka dia berhak atas mahar mitsil (mas kawin sepadan), karena menganggap halalnya hubungan seks itu. Jika mereka bermusuhan maka sultan (hakim) menjadi wali bagi perempuan yang tidak ada walinya. ${ }^{8}$

Pernyataan "nikahnya batal" dalam hadîts riwayat Zuhri tersebut ternyata dibantah oleh $\underline{H}$ anafi karena ketika Hanafi menanyakan tentang otentitas hadîts tersebut kepada Zuhri, ia tidak mengetahui dan mengingkarinya, sehingga Hanafi menganggap dalil hadîts tersebut tidak valid. ${ }^{9}$ Begitu juga hadîts: “Tidaklah perempuan menikahkan perempuan dan tidak (juga) menikahkan dirinya", 10 dan hadîts: "Janda lebih berhak atas dirinya dibanding walinya, sedangkan perawan dimintakan persetujuan atas dirinya."11 Menurut al-Syâfi'î, hadîts tersebut menunjukkan bahwa antara perawan dan janda terdapat perbedaan dalam mengungkapkan kesetujuan/izin. Izin seorang perawan diungkapkan dengan sikap diam dan sebaliknya izin seorang janda diungkapkan dengan berbicara. ${ }^{12}$ Sementara itu Ibnu Mundzîr mengatakan, bahwa persoalan tentang ungkapan kesetujuan perawan dengan bentuk diamnya dianjurkan untuk dikonfirmasikan kepada perawan, bahwa diamnya adalah persetujuannya. Akan

10Riwayat Abû Dâwûd dan Ibn Mâjah, lihat Ibn ㅂäajar al-Asqalâni, Bulûgh al-M arâm (Surabaya: al-Hidayah, t.t), hlm. 211-212. Lihat juga A bû Dâwûd, Sunan A bi D âwûd, “Kitab N ikah" no. 1784, Sunan al-Tirmidzî, "Kitab Nikah”, no. 1021, Ibn Mâjah , Sunan Ibn M âjah, "Kitab Nikah", no. 1869.

11 lihat A bû Zakâriya al-Anshârî al-Nawâwî, M ajmû' Syarh al-M uhadzdzab, XVII (Beirût: Dâr al-Fikr, 1996), hlm. 304.

12 Lihat Ibn Mâjah, Sunan Ibn M âjah (Beirût: Dâr al-Fikr, t.t), hlm. 610.

13Lihat Imâm Muslim, Shahîh M uslim, "Kitab Nikah", juz IV, 11. Lihat juga alTurmudzî, Sunan al-Turmudzî, “Kitab Nikah", no. 1026., al-Nasâ'i, Sunan al-N asâ'i, "Kitab Nikah", no. 3208.

14Lihat Idrîs al-Syafi'i, al-U mm, terj. Isma'il Ya'kub (Jakarta: Fajar, 1983), hlm. 372. Selanjutnya al-Syâfi'î membolehkan adanya pemaksaan nikah disertai beberapa syarat, di antaranya: (a) wali yang berhak melakukan ijbâr (wali mujbir) hanya ayah atau kakek, karena kasih sayang keduanya yang tidak diragukan, (b) anak yang diijbâr-kan masih gadis, dalam arti belum cukup dewasa untuk mengerti bagaimana sebaiknya hidup berumah tangga, kecuali janda, (c) calon suami yang dipilihkan harus sekufu' (setara), (d) adanya kemampuan untuk membayar mahar, (e) telah diketahui bahwa calon pilihan yang ingin di-ijbâr adalah pria yang sanggup memenuhi kewajiban nafkahnya. Lihat Muhammad al-Syarbînî, al-Iqnâ' (Surabaya: Dâr Ihyâ' al-Kutub al- 'A rabiyah, t.t.), hlm. 168. Lihat juga Zaitunah Subhan, Tafsir Keben cian: Studi Bias Gender dalam Tafsir Q ur'an (Yogyakarta: LKiS, 1999), hlm. 137. 
tetapi, bila setelah akad perempuan tidak mengetahui bahwa diamnya merupakan persetujuannya, maka menurut jumhûr, akadnya tidak batal. Perbedaan penafsiran seperti itu dimaksudkan sebagai suatu kejelasan bahwa persetujuan perempuan (dengan diam) itu mengarah kepada kerelaannya, sehingga bisa dinikahkan. Tetapi jika mengarah kepada bentuk penolakan, maka tidak bisa dinikahkan.13

Ada pemetaan penjelasan menarik yang dibuat oleh Ibn Rusyd tentang ikhtilâf ulamâ' berkaitan dengan hak bagi perempuan dalam menentukan jodoh dan kekuasaan wali sebagai berikut: Pertama, para ulamâ' sepakat bahwa untuk perempuan janda, maka harus ada ridlâ (kerelannya). Kedua, ulamâ' berbeda pendapat tentang seorang perempuan gadis yang sudah baligh. Menurut Imâm Mâlik, Imâm alSyâfi'î dan Abi laylâ, yang berhak memaksa perempuan yang masih perawan hanyalah ayah. Sedangkan menurut Abû Hanîfah, Imâm Tsawri, dan al-A wza'i serta sebagian lainnya mengharuskan adanya kerelaan atau persetujuannya. Ketiga, janda yang belum baligh, menurut Imâm Mâlik dan Abû Hanîfah, ayah dapat memaksanya untuk menikah. Sedangkan menurut Imam Syâfi'î tidak boleh dipaksa.

Sementara itu, ulama mutaakhkhirîn mengklasifikasikannya menjadi tiga pendapat, yaitu: (1) menurut Imâm Asyhâb bahwa seorang ayah dapat memaksa untuk menikahkan janda selama ia belum baligh setelah dicerai; (2) pendapat Imâm Sahnûn bahwa ayah dapat memaksanya walaupun sudah baligh; (3) pendapat Imâm Tamâm bahwa ayah tidak dapat memaksanya walaupun ia belum baligh. 14

\section{Kawin Paksa dalam Perspektif Perundang-undangan Negara Muslim M odern.}

Untuk dapat menghubungkan konsep ijbâr dan permasalahannya dengan konteks dewasa ini, maka penulis akan merujuk kepada beberapa perundang-undangan di beberapa negara Islâm modern. Indonesia, dalam kaitannya dengan ijbâr dan

15 al-A sqalâni, Fath al-Barî, hlm. 100.

16 Ibn Rusyd, Bidâyatul M ujtahid wa N ihâyatul M uqtashid, juz II (t.t.p.: Dâr al-Kutub alIslâmiyah, t.t.), hlm. 4. 
Abu Bakar

kebebasan dalam perkawinan, misalnya menetapkan bahwa perkawinan tanpa adanya wali adalah tidak sah dan diharuskan adanya persetujuan dari calon mempelai. ${ }^{15}$ A rtinya kalau kedua calon atau salah satunya tidak setuju, maka akad nikah tidak dapat dilaksanakan, dan oleh karena itu perkawinan tidak dapat terselenggara. 16

Selanjutnya, terkait dengan perundang-undangan di Malaysia baik undang-undang persekutuan maupun di tiap-tiap negara bagian, ijbâr dan kebebasan dalam pernikahan tetap diakui dan mewajibkan adanya wali dalam akad perkawinan. Konsekuensinya, apabila perkawinan dilaksanakan tanpa adanya wali, maka pernikahannya gagal. Kriteria wali adalah wali nasab dan bila terjadi persoalan atau kasus tertentu wali hakim bisa menggantikan wali nasab.17 Sedangkan persoalan kebebasan perempuan dalam memilih jodohnya, pada intinya semua hukum keluarga di negara bagian dan persemakmuran menghendaki adanya persetujuan dari pihak perempuan. Bahkan orang lain termasuk wali tidak boleh memaksa calon pengantin. Bila hal ini tetap dilakukan maka terkena denda seribu ringgit atau penjara maksimal enam bulan atau kedua-duanya. ${ }^{18}$

Untuk negara Maroko, adanya wali nikah dalam pernikahan tetap diwajibkan. Kalau walinya tidak mau menikahkan, maka bisa

17 Dalam Kompilasi Hukum Islam (KHI) pasal 14, "untuk melaksanakan perkawinan harus ada: (a) cal on suami, (b) cal on istri, (c) wali nikah, (d) dua orang saksi, (e) ijab qabul". 18UU no. 1 tahun 1974, pasal 6 ayat (1), "perkawinan didasarkan atas persetujuan calon mempelai" . Ayat (2), "bila ternyata perkawinan tidak disetujui oleh sal ah seorang mempelai, maka per kawinannya tidak dapat dilaksanakan".

19 Sebagaimana hasil penelitian Khoiruddin Nasutian tentang perbandingan hukum keluarga antara Indonesia dan Malaysia, disebutkan dalam beberapa UU negara bagian Malaysia, seperti UU untuk orang Islâm Selangor 1952, UU Islam Trengganu 1955, UU Agama Islam Pahan 1956, UU untuk orang Islâm Malaka 1959, sampai UU Islam Johor 1978. Yang pada intinya mensyaratkan wali dalam perkawinan serta adanya hak hakim untuk mengganti status wali nasab dalam kasus tertentu. Begitu juga tentang persetujuan perempuan dalam menentukan pilihan jodohnya. Selanjutnya lihat Khoiruddin Nasutian, Status Wanita di A sia tenggara,; Sebuah Studi Perbandingan Hukum Keluarga Indonesia dan Malaysia, (Yogyakarta: Disertasi IAIN Sunan Kalijaga, 2001), hlm. 250-252.

20 Lihat M. B. Hokker, UU Islam di A sia Tenggara (Kuala Lumpur: Ampang Press, 1992), hlm. 251. 
diganti wali hakim dengan syarat sekufu' (UU Maroko pasal 13).19 Tentang kebebasan perempuan dalam perkawinan, UU Maroko kurang tegas karena di satu sisi melarang adanya kawin paksa, di sisi lain masih dilakukan adanya ijbâr. $20 \mathrm{~N}$ amun pada intinya, persetujuan calon diharuskan dan secara implisit mengasumsikan pelarangan prinsip kawin paksa. Sedangkan negara Tunisia tidak mengharuskan adanya wali dalam perkawinan. Hal ini sesuai dengan UU Tunisia pasal 3 bahwa: "Perkawinan hanya dapat dilakukan dengan persetujuan kedua mempelai, disaksikan dua orang saksi dan sejumlah mahar untuk calon istri" .21

Berdasarkan pada paparan dalam aspek normatif-teoritis tersebut dapat dinyatakan bahwa pada dasarnya tidak ada pijakan yang jelas dalam al-Qur'ân tentang konsep ijbâr terhadap persoalan perkawinan anak perempuan. Al-Qur'ân hanya memuat asas dan norma yang sangat umum tentang persoalan perkawinan. Sedang dalam perspektif hadîts, walaupun banyak versi dan riwayat, namun secara substansial semua menekankan adanya persetujuan dari pihak perempuan dan kebebasan untuk menentukan pasangan hidup. Demikian pula dalam domain figh, meskipun beragam pendapat antara yang pro dan kontra terhadap konsep ijbâr, namun pada dasarnya konsep ijbâr dalam perspektif ulamâ' bukanlah pemaksaan yang semena-mena yang tidak bertanggung jawab, akan tetapi lebih merupakan hak bagi orang tua untuk mengarahkan putra-putrinya supaya dapat hidup bahagia. Dalam konteks inilah kemudian muncul persyaratan adanya kafâ'ah dan wali, meskipun masih sangat terbatas.

Adapun dalam konsep perundang-undangan modern, secara eksplisit dinyatakan bahwa persetujuan kedua calon mempelai merupakan suatu keharusan. Khusus dalam konteks Indonesia, walaupun pada intinya sama dengan negara Muslim lainnya, namun dalam banyak aspek termasuk struktur dan budaya hukum, belum

21 Lihat Tahir Mahmood, Personal Law in Islamic Countries ( $\mathrm{New}$ Delhi: Academic of Law and Religion, 1987), hlm. 120.

22 Lihat UU Maroko pasal 12 (ayat 2), dalam EI Alami and Hinchliffe, Islamic M arriage and D ivorce Laws of The A rab W orld (London: Kluwer Law International, 1996), hlm. 200.

23 Tahir Mahmood, Family Law Reform in The Muslim World (Bombay: NM Triphati PVT, 1972), hlm. 107. 
seluruhnya mendukung adanya kebebasan dalam perkawinan khususnya upaya menghilangkan praktik kawin paksa. Pertanyaanya kemudian adalah mengapa konsep yang secara teoritis sebenarnya baik dan syarat dengan muatan kemaslahatan dalam praktiknya menjadi sangat bersebrangan bahkan terkesan mengasumsikan kalau konsep ijbâr itu menjadi dalil legitimasi dan sekaligus penyebab adanya tradisi kawin paksa yang tidak humanis itu?

\section{Perkawinan Perspektif H umanistik}

Sering terdengar ungkapan bahwa jodoh berada di tangan Tuhan, meski ungkapan ini masih membutuhkan tafsir yang lebih spesifik. Masyarakat memandang bahwa jodoh bagi anak pria merupakan urusan Tuhan, sedang jodoh untuk anak perempuan menjadi urusan orang tua. Di masyarakat pedesaan, seorang gadis yang akan dikawinkan pada umumnya belum mengenal siapa calon pendampingnya sebab ada keyakinan yang telah dianggap 'lumrah' bahwa orang tualah yang menentukan secara sepihak calon suami anak gadisnya. Dalam istilah figh, hak orang tua ini disebut hak ijbâr.

Sebagai orang tua, selazimnya menginginkan kebahagiaan anak yang telah dikandung, dilahirkan dan diasuhnya dengan susah payah serta disayangi sejak dalam kandungan dan dibesarkannya. Keikutsertaan orang tua dalam memilihkan jodoh bagi anak tidak dapat dipermasalahkan atau disalahkan. Apabila menengok masa Ialu, kaum wanita tidak dapat disamakan dengan wanita masa sekarang, baik dari segi pendidikan, pengalaman, pergaulan dan kondisi lingkungan. Oleh karena itu, dianggap suatu kewajaran apabila ada orang tua ikut menentukan pilihan bagi anak-anaknya, bahkan menjadi tanggung jawab umat Islâm untuk memilihkan atau mencarikan jodoh baik bagi pemuda atau pun pemudi (siapa saja yang belum bersuami atau beristri). Demikian ini akan terlihat adanya kesejajaran dalam Islâm tentang "memilih"22 sesuai dengan firmanNya dalam surat al-Nûr (24): 32, “D an kawinkanlah orang-orang yang sendirian yang tidak beristri atau tidak bersuami di antara kamu." 23

22 Lihat Subhan, Tafsir Kebencian, hlm. 136-137.

23 Lihat Muhammad Fu'ad 'A bd al-Baqi, al-M uwaththâ' lî al-Imâm M âlik, jilid I, (M esir: Isa al-Bâbi al-Halabi), hlm. 107. 
Laki-laki atau pun perempuan mempunyai hak yang sama dalam memilih jodoh untuk menentukan siapa yang akan menjadi pendampingnya di masa depan demi keharmonisan, kebahagiaan, ketenangan, dan ketentraman dalam kehidupan keluarga. ${ }^{24}$ Karena itu, ajaran Islâm memberi tuntunan dalam menentukan pilihan. ${ }^{25}$ Dalam kehidupan, hak ijbâr ini tidak lagi dapat dipertahankan, apalagi hal ini bertentangan dengan prinsip kemerdekaan. Kemerdekaan dalam memilih jodoh telah ditegaskan dalam Islâm melalui pernyataan Rasûlullâh SAW ketika beliau didatangi oleh seorang gadis sambil mengadukan tentang ayahnya yang telah memaksanya untuk kawin dengan seseorang yang tidak ia senangi, Rasûlullâh SAW memutuskan agar urusan perkawinan tersebut dikembalikan kepada anak gadis itu untuk memilih. ${ }^{26}$

Islâm bercita-cita untuk menciptakan suatu masyarakat religius yang penuh damai dan rukun. Hal ini tidak mungkin tercapai kecuali bila masing-masing keluarga hidup dengan rukun dan tenteram. Kesakinahan di dalam keluarga baru terwujud bila antara masingmasing pihak (suami dan istri) terjalin cinta, kasih sayang yang tulus dan mendalam. Hal ini tak mungkin datang dengan tiba-tiba, melainkan harus diawali sejak dini jauh sebelum melangkah ke perkawinan, para calon suami-istri perlu ada kesesuaian. Untuk mendapatkan kesesuaian tersebut, maka Islâm memberikan hak yang sama dalam menentukan jodoh. Dengan demikian, wanita bebas menerima atau menolak pinangan seseorang atau pilihan orang tuanya, jika pria yang disodorkan tidak cocok dengan harkat dan martabat si wanita tersebut terutama dalam bidang agama.27

Wanita memiliki hak prerogatif dalam urusan perkawinan yang selama berabad-abad sebelum kedatangan Islâm hak itu tak pernah diberikan sebagaimana telah diuraikan. Agaknya, tak perlu diulang lagi pembahasannya mengapa hak mereka tidak diberikan pada masa lampau. Tapi yang perlu dicermati di sini menurut hemat penulis

24 Lihat QS. al-Rûm (30): 21.

25 Subhan, T afsir Kebencian, hlm. 138.

26 Lihat Nasharuddin Baidan, Tafsir bi al-Ra'yi: U paya Penggalian K on sep W anita dalam al-Q u r'an (Yogyakarta: Pustaka Pelajar, 1999), hlm. 72.

27 Lihat A bu Zayd, M akân at al-M ar'ah fî al-Islâm (t.t.p.: Dâr al-Nahdhah al-'A rabiyah, 1979), hIm. 95. 
adalah bahwa pemberian hak tersebut tidak berarti orang tua atau wali tak punya hak sama sekali dalam urusan perkawinan putraputrinya. Pemberian hak seperti yang telah dijelaskan itu mengandung arti bahwa orang tua, meskipun secara relatif berwenang terhadap anak-anaknya, namun ia tidak boleh sewenangwenang terhadap mereka karena ada aturan-aturan yang harus diikuti dan dipatuhi.

Oleh karena itu, apabila seorang gadis telah mendapatkan jodoh dan pria pilihannya itu tidak bertentangan dengan ajaran agama, misalnya dia seorang yang taat, berakhlak mulia, tapi miskin atau tidak bangsawan, maka orang tua tidak boleh menolaknya dengan alasan calon menantunya tidak bangsawan atau miskin. Karena itulah, Rasulullah tidak merasa malu mengawinkan Zaynab binti Jahsy, saudara sepupunya sendiri (bangsawan Quraysy) dengan Zayd bin Harîtsah yang dulunya seorang budak belian, kemudian diangkat anak oleh Rasulullah. Demikian pula 'A bd Rahmân bin 'Awf seorang bangsawan yang kaya raya tidak merasa rendah, apalagi hina saat mengawinkan saudara perempuannya dengan Bilâl bin Rabah yang dulunya seorang budak hitam milik tokoh musyrik Mekkah, Umaiyah bin Khalâf.28

Dalam Islâm, tradisi yang potensial untuk memicu kerawanan dan kesenjangan sosial itu dihapuskan secara total sehingga terasa sekali bahwa manusia itu benar-benar sama derajadnya, tidak ada kelebihan yang satu dari yang lain dari sudut keturunan dan kekayaan kecuali dari segi ketakwaan individual terhadap Allâh SWT. Berdasarkan petunjuk-petunjuk yang diberikan oleh Allâh SWT. dan Rasûl-Nya serta sejumlah fakta historis sebagaimana telah dipaparkan, semakin jelas bahwa kebebasan perempuan dalam memilih calon suaminya tetap harus terkendali dan tidak menyimpang apalagi bertentangan dengan ajaran agama.

28 Lihat Ahmed, Wanita dan Gender dalam Islam: A kar-akar H istoris Perdebatan M odern (Jakarta: Lentera, 2000), hlm. 6-7. 
Kawin Paksa

\section{Dampak Kawin Paksa terhadap Perempuan.}

\section{Hegemoni Laki-laki atas Perempuan.}

Sepanjang sejarah sampai munculnya Islâm, kekuasaan dan otoritas hanya milik suami dan ayah, istri dan anak harus patuh dan taat sepenuhnya. Sebuah teks dari paruh milenium ketiga sebelum masehi mengatakan bahwa seorang istri yang menentang suaminya boleh dirontokkan giginya dengan batu bata, dan Kode $\mathrm{Hammurobi}$ menetapkan bahwa seorang anak harus dipotong tangannya apabila memukul ayahnya. Kepala keluarga berhak mengatur perkawinan anak-anaknya dan mempersembahkan anak perempuannya kepada para Dewa.29 Penindasan dan penomorduaan terhadap perempuan ini merupakan akibat dari tatanan patriarkhi yang menghujam sangat dalam dalam praktik budaya waktu itu. ${ }^{30}$

Dominasi laki-laki secara kuat tidak bisa dipisahkan dari faktor struktur hukum dan sosial yang mengitarinya. Hukum dan juga lingkungan memberikan kepada laki-laki kekuasaan yang cukup besar terhadap perempuan. Menurut hukum Islâm, laki-laki mempunyai hak prerogatif yang besar untuk menjatuhkan perceraian, sementara perempuan terlalu sempit haknya.31 Di samping itu, relasi gender juga sangat dipengaruhi oleh adanya pembagian peran dan fungsi dalam masyarakat. Dalam masyarakat Arab, laki-laki bertugas membela dan mempertahankan seluruh anggota keluarga, bertanggung jawab memenuhi seluruh kebutuhan keluarga. Konsekuensinya, laki-laki memonopoli kepemimpinan dalam semua tingkatan. Artinya, promosi karier dalam berbagai profesi dalam masyarakat hanya bergulir di kalangan laki-laki, sedangkan perempuan hanya mengurusi urusan yang berhubungan dengan reproduksi. 32

\footnotetext{
29 Lihat Wahiduddin Khan, Between Islam and Western Society, terj. Abdullah Ali (Jakarta: Serambi IImu Semesta, 2001), hlm. 51-52.

30 Ira M. Lapidus, Sejarah Sosial U mat Islam, terj. Gufran A. Mas'di (Jakarta: Raja Grafindo Persada, 1999), hlm. 530.

31 Nasaruddin Umar, Argumen Kesetaraan Gender dalam Perspektif al-Q ur'an (Jakarta: Paramadina, 1999), hlm. 135.

32 Sri Handayani Hanum, Perkawinan U sia Belia (Yogyakarta: PPK UGM, 1997), hlm. 22.
} 
Salah satu contoh hegemoni laki-laki atas perempuan adalah prosesi perjodohan perempuan di bawah umur. Pada umumnya mereka tidak mengetahui karakter calon suaminya, sehingga pada banyak aspek telah menimbulkan rasa cemas, stress, takut, segan, dan marah, atau bahkan melarikan diri dari suami. Sebenarnya para perempuan yang menikah di bawah umur itu masih enggan berumah tangga. Akan tetapi mereka terpaksa menjalaninya karena alasan untuk menghormati orang tua.33 Dalam istilah lain dapat dinyatakan bahwa hegemoni peran orang tua dalam perkawinan anak perempuan itu sangat kuat. Bagi anak perempuan hampir-hampir tidak mempunyai hak untuk menolak perkawinan yang ditawarkan oleh orangtuanya. Inilah salah satu faktor penyebab terjadinya praktik kawin paksa, yaitu kuatnya budaya dan adat yang bersifat patriarkhi.

\section{D ampak Ketidakberdayaan secara Psikologis}

Manakala kawin paksa benar-benar terjadi, maka perempuan dalam hal ini adalah istri menjadi korban pertama dan utama. Dalam masyarakat yang bersistem kebapakan seperti di Jawa, perempuan sering menjadi pihak yang selalu dipersalahkan atau dijadikan kambing hitam. Atmosfer penghukuman sosial dan dinamika menyalahkan istri dalam problem rumah tangga (blaming the victim) tidak lagi menyediakan ruang gerak yang memungkinkan perempuan dipandang sebagai manusia yang utuh dengan spektrum yang luas, yang selain memiliki sisi kelemahan juga memiliki sisi baik.34 Dilihat dari perspektif psikologi eksistensialisme dapat diinterpretasikan bahwa perkawinan paksa serta merta menimbulkan kecemasan karena si pelaku menghayati dirinya tidak punya kemampuan, wewenang, dan pilihan terhadap keputusan apa pun. Upaya mendongkrak dan menolak tentu malah menjadi persoalan dengan orang tuanya, apalagi perkawinan paksa telah disetujui oleh orang tua kedua belah pihak. Pada keluarga tradisional terdapat anggapan bahwa perempuan yang sudah menikah harus ikut dan

33 Yahya Kishbiyah, et.al., Kehamilan Tak D ikehendaki di Kalangan R emaja (Yogyakarta: PPK-UGM, 1997), hlm. 48-49.

34 Ibid., hlm. 49-50. 
menerima suaminya secara totalitas. Jika tidak, maka dianggap menyalahi kebiasaan umum yang terjadi. 35

Pada aspek psikologis, sebuah perkawian memiliki beberapa kriteria baik yang bersifat mental maupun spiritual. Secara mental, pasangan suami istri hendaknya saling mengetahui kepribadian masing-masing sehingga mampu menyesuaikan diri, terutama jika dalam perjalanan perkawinannya terdapat gejolak atau perbedaan akan bisa diatasi. Secara spiritual, kecerdasan dan pendidikan khususnya pendidikan agama, pemahaman, dan pengamalannya harus diperhatikan, karena pada dasarnya perkawinan adalah perwujudan dari kehidupan agama. 36

Kawin paksa yang dialami oleh banyak perempuan pada dasarnya secara psikologis tidak dapat dibenarkan, karena ada banyak konsekuensi negatif baik menyangkut sisi kesehatan fisik maupun psikis. Konsekuensi psikis muncul pertama kali pada saat perjodohan dilaksanakan karena pada saat perempuan dijodohkan dengan laki-laki yang tidak ia kehendaki, seketika itu juga mulai timbul gejolak, pertentangan dalam hatinya, perasaan shock, dan waswas. Untuk selanjutnya, hal ini dapat menimbulkan perubahan sikap keseharian menjadi pendiam (silent girl) dan pemurung. ${ }^{37}$

Perasaan nervous dan stress serta perasaan-perasaan lainnya akan terus berlanjut hingga awal kehidupan perkawinan. Malam pertama merupakan malam yang menyeramkan karena dengan terpaksa harus melayani suami sebagai suatu pengalaman yang membuatnya tidak berdaya dan tidak tahu apa yang seharusnya dilakukan. Di sinilah muncul penyesalan bagi perempuan dan apabila kondisi itu terus berlanjut, maka sebagai konsekuensi terburuknya adalah terjadinya kekerasan dalam rumah tangga dan berujung pada perceraian.

35 Dadang Hawari, al-Qur'an IImu Kedokteran Jiwa dan Kesehatan Jiwa (Yogyakarta: Dhana Bakti Prima Yasa, 1995), hlm. 211-212.

36 Sebagai dikutip Hanum, P erkawinan U sia Belia, hlm. 64. 


\section{Penutup}

Berdasarkan uraian di atas, dapat disimpulkan bahwa al-Qur'ân secara eksplisit tidak menyinggung konsep kawin paksa apalagi menganjurkannya. Sedangkan dari sejumlah hadîts tentang hak ijbâr dan kebebasan perempuan dalam menentukan pasangan hidupnya muncul dalam berbagai variannya dan tidak bisa dilepaskan dari asbâb al-wurûd-nya. Sejumlah hadîts tersebut pada prinsipnya menekankan pada pentingnya persetujuan perempuan yang bersangkutan. Konsekuensinya, terdapat perbedaan pendapat di kalangan ulamâ' tentang konsep ijbâr.

Konsep ijbâr secara teoritis pada awalnya merupakan hak dan kewajiban orang tua dengan rasa tanggung jawab untuk mengarahkan anak perempuannya ke arah perkawinan yang yang ideal menurut Islâm. Namun, dalam realitas empirik telah terjadi distorsi makna dan hakikat konsep ijbâr tersebut. Hal ini terjadi karena tradisi ijbâr pada masa klasik yang terekam dan terjabarkan dalam konsep-konsep fiqh tentang pernikahan ternyata tidak dapat dipisahkan dari cerminan budaya patriarkhi yang dominan pada saat itu. Karenanya, dalam konteks modern, sudah saatnya perlakuan otoritarianisme terhadap perempuan dihapuskan karena ia merupakan salah satu wujud dehumanisasi yang bertentangan dengan norma agama, sosial, hukum, dan keadilan.

\section{D aftar Rujukan}

Ahmed, Wanita dan Gender dalam Islam: A kar-akar Historis Perdebatan M odern. Jakarta: Lentera, 2000.

Alami, El dan Hinchliffe. Islamic M arriage and D ivorce Laws of The A rab W orld. London: Kluwer Law International, 1996.

A shqalânî, Ibn 브ajar al-. Fath al-Barî. t.t.p: Mathba'ah al-Salafiyah, t.t. Bulûgh al-M arâm. Surabaya: al-Hidâyah, t.t.

Baidan, Nasharuddin. Tafsir bi al-Ra'yi: U paya Penggalian Konsep W anita dalam al-Q ur'an. Yogyakarta: Pustaka Pelajar,1999. 
Baqi, Muhammad Fu'ad 'Abd al-. al-M uwaththâ' lî al-Imâm M âlik. Mesir: Isa al-Bâbi al-Halabi.

Bayhaqî, al-. al-Sunan al-Kubrâ, Berût: Dâr al-Fikr, t.t.

Hanum, Sri Handayani. Perkawinan U sia Belia. Yogyakarta: PPK UGM, 1997.

Hawari, Dadang. al-Qur'an Ilmu Kedokteran Jiwa dan Kesehatan Jiwa. Yogyakarta: Dhana Bakti Prima Yasa, 1995.

Hokker, M. B. UU Islam di Asia Tenggara. Kuala Lumpur: Ampang Press, 1992.

Indraswati, "Fenomena Kawin Muda dan Aborsi", dalam Syafiq Hasyim (ed.), M enakar H arga Perempuan, Jakarta: Mizan, 1999.

Jawziyyah, Ibn al-Qayyim. al- I'lâm al-M uwaqqi'în 'an Rab al-'Âlamîn. Berût: Dâr al-Fikr, 1997.

Jazâirî, Abdurrahman al-. al-Fiqh 'alâ M adzâhib al-Arba'ah. Beirût: Mathba'ah al-Salafiyah, t.t.

Khan, Wahiduddin. Between Islam and Western Society, terj. Abdullah Ali. Jakarta: Serambi IImu Semesta, 2001.

Kishbiyah, Yahya et.al. Kehamilan Tak Dikehendaki di Kalangan Remaja. Yogyakarta: PPK-UGM, 1997.

Lapidus, Ira M. Sejarah Sosial U mat Islam, terj. Gufran A. Mas'adi. Jakarta: Raja Grafindo Persada, 1999.

Mahmood, Tahir. Family Law Reform in The M uslim World. Bombay: NM Triphati PVT, 1972.

-------. Personal Law in Islamic Countries. New Delhi: Academic of Law and Religion, 1987.

Mâjah, Ibn. Sunan Ibn M âjah. Beirût: Dâr al-Fikr, t.t.

Nawâwî, Abû Zakâriya al-Anshârî al-. M ajmû' Syarh al-M uhadzdzab. Beirût: Dâr al-Fikr, 1996.

O'Dea, Thomas F. Sosiology of Religion, terj. Tim Penerjemah Yosagama. Jakarta: Rajawali, 1990. 
Rusyd, Ibn. Bidâyat al-M ujtahid wa N ihâyat al-M uqtashid. t.t.p.: Dâr alKutub al-Islâmiyah, t.t.

Soekanto, Soerjono. Pokok-Pokok Sosiologi Hukum. Jakarta: Raja Grafindo, 2001.

Subhan, Zaitunah. Tafsir Kebencian: Studi Bias Gender dalam Tafsir Q ur'an. Yogyakarta: LKiS, 1999.

Syâfi'î, Muhammad Idrîs al- al-U mm, terj. Isma'il Ya'kub. Jakarta: Fajar, $19 \overline{9} 83$.

Syarbînî, Muhammad al-. al-I qnâ'. Surabaya: Dâr Ihyâ' al-Kutub al'A rabiyah, t.t.

Umar, Nasaruddin. Argumen Kesetaraan Gender dalam Perspektif alQ ur'an. Jakarta: Paramadina, 1999.

Zayd, Abu. M akânat al-M ar'ah fî al-Islâm. t.t.p.: Dâr al-Nahdhah al'A rabiyah, 1979. 